\title{
Business recovery in the European Union after the global financial crisis: lessons for the Coronavirus pandemic
}

\author{
Consuela-Elena POPESCU*, Alexandra HOROBET ${ }^{* *}$, \\ Georgiana VRINCEANU***, Lucian BELASCU****
}

\begin{abstract}
The present paper undertakes an analysis of the manufacturing sector performance in the European Union after the 2007-2009 Global financial crisis, with the aim of discovering the lessons to be learned for the post-pandemic world. We employ aggregate data at industry level and use a methodology based on mean difference tests and two-samples Kolmogorov-Smirnoff tests. We find a varied panorama of industry recovery in EU after the 2007-2009 crisis, albeit with different paces depending on size, ownership, and level of technological intensity. There is evidence of a higher flexibility of smaller companies, reflected mostly in productivity gains, and a focus of larger businesses on profitability, supported by their size. Moreover, better personnel cost management has led to a drop in the importance of personnel costs in turnover. Our results are valuable for businesses that needed to survive during the pandemics, as they show that higher business flexibility might support a quicker recovery.
\end{abstract}

Keywords: crisis, recovery, manufacturing, lessons, coronavirus

\section{Introduction}

The "Future of manufacturing in Europe" is a project proposed by the European Parliament and delegated to the European Foundation for the Improvement

\footnotetext{
* Consuela-Elena POPESCU is PhD candidate at University of Economic Studies, Bucharest, Romania; e-mail: consuela.popescu@rei.ase.ro.

** Alexandra HOROBET is Professor at University of Economic Studies, Bucharest, Romania; e-mail: alexandra.horobet@rei.ase.ro.

*** Georgiana VRINCEANU is PhD candidate at University of Economic Studies, Bucharest, Romania; e-mail: vrinceanugeorgiana16@stud.ase.ro.

${ }^{* * * * *}$ Lucian BELASCU is Professor at Lucian Blaga University of Sibiu, Bucharest, Romania; e-mail: lucian.belascu@ulbsibiu.ro.
} 
of Living and Working Conditions in the context of emerging digital technologies and the challenges of new forms of international competition. After years of research reports, seminars, and debates, the conclusion is that manufacturing remains an important pillar in the economic development of Europe (Storrie, 2019).

Manufacturing contributed to $22.8 \%$ of the employment within the EU27 nonfinancial business economy and accounted for more than one quarter of the total value added within the same nonfinancial business economy (according to Eurostat). In addition, the total number of enterprises operating in the manufacturing sector represented roughly $9 \%$ of the total number of enterprises in the EU and accounted for 28\% of the turnover at the EU level in 2017 (according to Eurostat). According to official statistics, the labour productivity (measured as Apparent labour productivity - value added at factor costs divided by the number of persons employed) of the manufacturing sector was EUR 14,500 in 2017, above the nonfinancial business economy average (EUR 64000 per person employed in manufacturing versus EUR 49500 per person employed in the nonfinancial business economy).

The manufacturing's role and position is changing and the way it contributes to the economy shifts as nations mature (McKinsey et al., 2012). In advanced economies, it promotes innovation, productivity, and trade more than growth and employment. In these countries, manufacturing is using more than ever services provided by companies operating in different sectors. By contrast, in developing countries, it contributes to the pathway from subsistence agriculture to rising living standards. Thus, innovation in the before-mentioned context means the application and development of ideas and technologies that improve goods and services or make their production more efficient (European Central Bank, 2017).

In the last years, physical activities in the manufacturing sector declined because of automation of processes and this was perceived as the main cause for the loss of jobs (Storrie, 2019). However, if workers can be adequately trained for the labour market, they can be directed into more intellectual rather than physical tasks. Over the long term, this is considered a strategy that leads to social and economic success. Results show that proactivity in the commercial adoption of emerging technologies and innovation will create more jobs and will ensure Europe's competitive advantage over its main competitors, the United States and China. Additionally, participation in international production networks or global supply chains has the potential to bring enhanced growth and employment opportunities for the EU (Eurofound, 2019). This need arises as the application of technology is limited and mainly restricted to highly productive companies.

Innovation, understood in its broad sense of technological development of a product and the market introduction of the respective product (Popescu, 2015), contributes to the strengthening of an economy in various ways (Hausman et al., 2014). First and foremost, it creates jobs which result in income for the workers that ultimately spend their money in the economy by purchasing products and services 
but also by paying taxes which fuel economic growth. Second, innovative products improve standards of living as they make life easier and more enjoyable for individuals but also provide new means for detecting and curing diseases. Last but not least, innovation creates new and better tools to defend citizens, which increases national security overall. Applegate et al. (2009) stress that "the financial crisis provides a sobering reminder of what happens when innovation fails to drive productive economic growth". Moreover, the complexity of the nowadays networked economy brings challenges for business competitiveness and puts firms in the difficult position to redefine their business models and strategic options (Herciu, 2015).

As the EU will continue to face protectionism coupled with the outcome of the Paris Agreement on Climate Change (UNFCCC, 2015) for a successful transition to a low-carbon economy, only a high commitment to effective management of the transition and adaptation to economic and industrial change will ultimately benefit consumers and keep the material welfare enjoyed by EU citizens (Storrie, 2019).

Considering the health crisis generated by the current global pandemic and its likely continuation in the years to come, we believe that businesses and governments alike have lessons to learn from the Global financial crisis (GFC) of 2007-2009. Both crises have been similar in terms of uncertainty generated and location where they started, i.e., two major economies (the US for GFC and China for Coronavirus). Next, they have both been considered as serious as the Great Depression of 19291933 since the initial plunge in stock exchanges in major economies was around $25 \%$. Finally, monetary and fiscal policies have been used as government-provided support during both crises (full-time jobs transformed into part-time or technical unemployment paid by governments over firing massive numbers of employees because of Covid-19, banks and other companies bail-outs, fiscal stimulus and deep cuts in policy interest rates in the case of GFC). Differences between the two reside in the fact that the Covid-19 crisis is health-related, which subsequently led to an economic crisis, while the GFC started as a housing bubble which affected financial institutions and then led to a financial crisis, first in the United States and, afterwards, around the world through contagion effects.

From this perspective, our research offers insight into the challenges that industries from the manufacturing sector have been confronted with in the recovery period after the GFC, considering three main business attributes: industry's technological level (high-tech versus low-tech), business ownership (foreign versus local), and business size (small and high). Specifically, we investigate the differences in performance experienced by various industries in the manufacturing sector between 2009 and 2016 to juxtapose the previous economic downturn to the current one and extract lessons that can be applied for a smoother and faster recovery.

Our paper is structured as follows. The next section offers insights into the research directions and evidence in the existing literature. Further, the Data and Methodology section describes the data used in our research and details the research 
methodology, followed by the presentation of the most important results. Finally, the conclusions part discusses the implications of our findings, the research limitations, but also directions for future research.

\section{Literature review}

Our research is placed at a crossroads between manufacturing sector performance, and innovation and technological advancement as major drivers of economic growth in the context of the GFC.

The GFC of 2008 has revived the arguments about the role of manufacturing and its importance for economic growth and countries' international competitiveness. Thus, a renewed interest in reindustrialization and specific policies came into discussion. Damiani et al. (2014) studied the main characteristics and changes in manufacturing in the past twenty years in the EU and highlighted that member states underwent significant structural changes in their economies, with services becoming the prevalent sector in terms of turnover, employment and contribution to GDP. The authors extrapolate this reindustrialization to Western Balkan countries as they drive on the deindustrialization route and stress the importance of industrial policies to strengthen their manufacturing industries, to promote export-led growth and increase economic development in their journey towards EU membership. Similarly, Haraguchi et al. (2017) argue that the importance of manufacturing for economic development in emerging countries is still central and will remain so in the future as these countries will enter a mature stage of industrialization and can take advantage of their backwardness relative to the more developed countries.

Moving forward, by using a rich-firm level dataset, Dabla-Norris et al. (2010) bring into discussion and demonstrate that innovation directly influences productivity, and this is more significant for countries with well-developed financial markets and for companies in high-tech sectors. Authors explain that, by facilitating technological innovations and low-cost production methods, productivity is encouraged and, eventually, this leads to economic growth. Furthermore, Haq (2018) uses panel methodologies to demonstrate that FDI inflows, R\&D expenditure, hightechnology exports, patent application residents and research in the amount of scientific and tech journal articles directly and positively influence economic growth and development. Petrariu et al. (2013) apply similar proxies for measuring innovation ( $R \& D$ expenditure, patenting, number of researchers, mergers and acquisitions) in order to demonstrate that innovation is directly related to competitiveness and economic growth in the case of CEE countries. They also remind the readers that the economic gap between Western and Eastern Europe can be filled by investing in innovation. A later study from Pece et al. (2015), focused on the long-term effects of innovation on economic growth and applied to CEE countries, uses multiple regression to highlight that foreign direct investment 
(through knowledge transfer and improvement of technological processes), coupled with investment in education and human capital, can have a strong impact on economic wellbeing.

Focusing on economic crisis, Van Ark and Jager (2017) analyse the sectorlevel growth and productivity at EU level for the years following the global recession (up to 2015) and find that the latter damaged the growth pattern of all European countries under investigation (EU16) in a significant way. Except for Germany, none of the remaining 15 states recovered to their growth levels before the GFC. The slowing growth is driven by employment stagnation, modest recovery in capital input growth and a weakening of the total factors of productivity growth rate. Of all economic sectors, manufacturing was particularly hit by the downturn as it lost in terms of output, investments, and productivity growth. On the contrary, authors conclude that the services sector has increased in importance and recovered slightly better than manufacturing. In the same vein, the Finnish manufacturing sector was badly hit by the GFC as exports at the end of 2013 were at the level of 2006, and employment has been declining by roughly $15 \%$ and nearly one fourth of their 2000 level since the beginning of the GFC. The authors argue that manufacturing companies in Finland should change their strategy and emphasize more product development, broadness of product line and after-sales service, while keeping the focus on delivery speed and punctuality. They find that, for SMEs in manufacturing, the after-sales service increases revenues and their ability to introduce new products improves profits.

Another interesting idea is raised by Cainelli et al. (2018) and deals with regional resilience over the 2008-2012 GFC period. The authors analyse the relationship between industrial relatedness (when local industries exploit similar inputs or skills) and economic resilience across EU regions (16 countries) and build on the evolutionary approach which states that the role played by a region's current industry structure is a potential determinant of its capacity to absorb an external shock in the short run or to develop new growth patterns in the long run. Their results indicate that technological relatedness has a positive effect on the resilience probability in the short run, while vertical relatedness has a negative effect on the same variable and persists over longer periods of time. Cowling et al. (2017) undertake a research on small business growth by using two alternative measures of business growth (the percentage change in employment and sales) to explain small businesses' performance after the GFC. Their findings reveal that older firms' recovery process took longer than younger firms'; however, entrepreneurial experience had no effect on the pace of the recovery. Coming back to the resilience concept mentioned before, Cowling et al. (2017) demonstrate that the growth performance of SMEs is unevenly distributed across sectors, which shows that, in a recession, certain types of SMEs are more resilient than others. We add here the interesting findings of Božić and Botrić (2017), which reveal the different effects of process and organizational innovation on businesses' future decisions regarding 
investments in innovation in countries with different economic levels, i.e., (post)transition and developed economies.

Moving further, another interesting study by Karacay (2017) investigates 671 Western European manufacturing firms by comparatively examining their organizational management and performance characteristics before, during and after the GFC of 2008. The author uses panel data, multivariate tests and multiple regression models and shows that the impact of GFC on company performance was negative and significant and that the slack-performance (implying the availability of resources) has a positive but curvilinear relationship (describes more complex relationships as the nature of these relationships is different at different levels of the variables), stressing that the more available resources are, the better a company performs. During financial crises, companies prefer to use strategic resources (like inventory, dividends, working capital, $R \& D$ and marketing expenses) instead of operational resources (like human resources, leverage and asset utilization) to respond quicker to potential changes and opportunities in the business environment while the opposite happens in normal times. Simultaneous ambidexterity (firms' capacity to effectively manoeuvre at the edge of adaptability-alignment trade off) seems to be an important factor when showing resilience during turbulent times (which is considered an asset for a company to sustain long-run competitive advantage over time).

Cucculelli et al. (2015) analyse how organizational learning and firm internal factors (CEO's origin, tenure, and turnover) influence firms' response to the economic crisis in small and medium family firms. Authors find that learning from a crisis was not necessarily the outcome observed, even following a CEO change. However, if the CEO came from the owning family and after a certain period, the CEO turnover did improve learning from a recession. In the same vein, Cucculelli et al. (2017) look at the role of learning from a crisis on the entrepreneurial ability of a SME to adapt to a new competitive landscape through the adoption of a new or renewed business model. They investigate the impact of changes occurred in business models on the probability of default by using a set of measures such as the degree of vertical integration, the intensity of investments in intangible assets and the complexity of external services network. Their results indicate that the probability of default of a company increases with the complexity of the business model adopted previously (as measured by the firms' vertical integration and the complexity of the network of external services) while it decreases with the intensity of investment in intangible assets.

Notta et al. (2014) assess the effect of the GFC on Greek food manufacturing firms' performance and use a model employing market share, capital intensity, liquidity, leverage and equity coverage of fixed assets index (measured by the net worth to fixed assets which shows the ability of a company to cover long run investment with its own capital). Before the 2008 GFC, it was only the market shares which positively influenced the profitability of Greek companies, but during the 
GFC, market share, liquidity and leverage all explained performance (the first two variables in a positive way while the last variable in a negative way). Thus, the larger the market share of a company, the more competitive and profitably stable it is. Liquidity is essential for the survival and competitiveness of manufacturing companies during economic downturns. Referring to the Greek Manufacturing sector, Voulgaris et al. (2014) explore the factors affecting job creation and job destruction, distinguishing between the pre-GFC (2004-2007) and post-GFC (20082011) periods. They find that food companies were less affected than textiles, wearing apparel and leather products. They also demonstrate that old firms (which have passed the test of time because of their established name and position on the market), major exporters (that increase sales by exporting and, as a result, create new jobs), new investments in fixed assets (used as a proxy for new technology application and innovation) are significant job creators, while large firms (that tend to be more profitable, but profitability is negatively correlated with job growth) are mainly job destructors. All in all, considering their findings, discretionary microeconomic policies that encourage exports, production coupled with tax reductions, investment subsidies and export grants in favour of the mostly affected sectors could reduce unemployment in Greece. As a rise in unemployment is one of the consequences of economic crises, these findings and recommendations can be extrapolated to the current pandemic situation and to the scenario that can possibly arise soon.

\section{Data and methodology}

We have included in our analysis 11 industries from the EU manufacturing sector, which have been divided into high-tech and low-tech industries according to the EU High-tech classification of manufacturing industries based on NACE Rev.2 2-digit codes: Low-tech - C10 (Manufacture of food products), C13 (Manufacture of textiles), C16 (Manufacture of wood and of products of wood and cork, except furniture; manufacture of articles of straw and plaiting materials), C18 (Printing and reproduction of recorded media), C22 (Manufacture of rubber and plastic products), C25 (Manufacture of fabricated metal products, except machinery and equipment), C31 (Manufacture of furniture); High-tech - C20 (Manufacture of chemicals and chemical products), C27 (Manufacture of electrical equipment), C28 (Manufacture of machinery and equipment), C29 (Manufacture of motor vehicles, trailers and semi-trailers).

The period covered in this analysis is 2009-2016 and our sample, based on data availability from Eurostat, includes $20 \mathrm{EU}$ member countries (at the end of 2016): Austria, Bulgaria, Czech Republic, Finland, France, Germany, Greece, Hungary, Italy, Latvia, Lithuania, the Netherlands, Poland, Portugal, Romania, Slovakia, Slovenia, Spain, Sweden, and the United Kingdom. 
We employ aggregate data at industry level for the following performance variables: turnover, value added, personnel costs, gross investments in tangible goods, simple wage-adjusted labour productivity, and gross operating rate. Using turnover, value added, gross investments, and personnel costs, we have constructed three relative performance indicators - VATurn (the share of value added in turnover), GITurn (the share of gross investments in turnover), and PcostTurn (the share of personnel costs in turnover). These three variables were used in the research, along with GOR (gross operating rate) and SWALP (simple wage-adjusted labour productivity). The unit of analysis in our research is the "business unit", which is defined on three parameters: the industry (11 industries, classified into low-tech or high-tech), the country, and the ownership (foreign versus local). Thus, each business unit should be describing the average performance of a company in the respective industry by considering the previously-mentioned parameters.

Firstly, we have split the business units according to their ownership in foreign versus locally-owned, then, according to their technological intensity, in high-tech companies and low-tech companies. Subsequently, we calculated the median of turnover for each ownership category, foreign versus local, and we have included the business units with a turnover above the median in the "big business units" category, and the ones with a turnover below median in the "small "business units" category. To provide more granularity to the data, which allows for more insight into business performance, we have also split the countries according to their geographic position into Eastern Europe and Western Europe-located.

The first observation is that the majority of locally-owned low-tech companies are smaller in size than their high-tech counterparts, regardless of the East-West location (see Figures 1 to 3). At the same time, in the case of foreign-owned lowtech business units, Eastern Europe business units seem to be smaller in terms of size than their Western counterparts; the same observation applies to foreign-owned high-tech Eastern companies, which are smaller in size than their Western counterparts. Last but not least, high-tech companies are generally bigger in size than low-tech companies (based on the median), and if a closer look is taken at the split between foreign and local, we observe that foreign companies are equally small and big in size, while local companies are mostly smaller in size. 
Figure 1. Business units' distribution in the EU based on the ownershiptechnological intensity

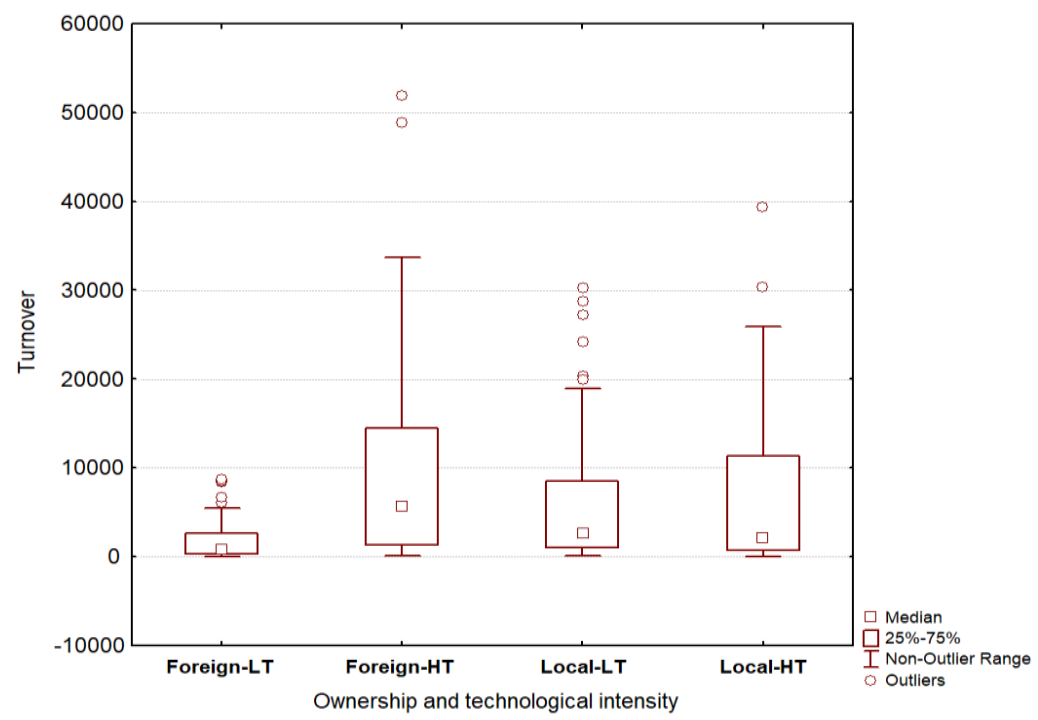

Source: Authors' representation

Figure 2. Business units' distribution in the EU based on the ownership technological intensity - EU region triad: Eastern Europe

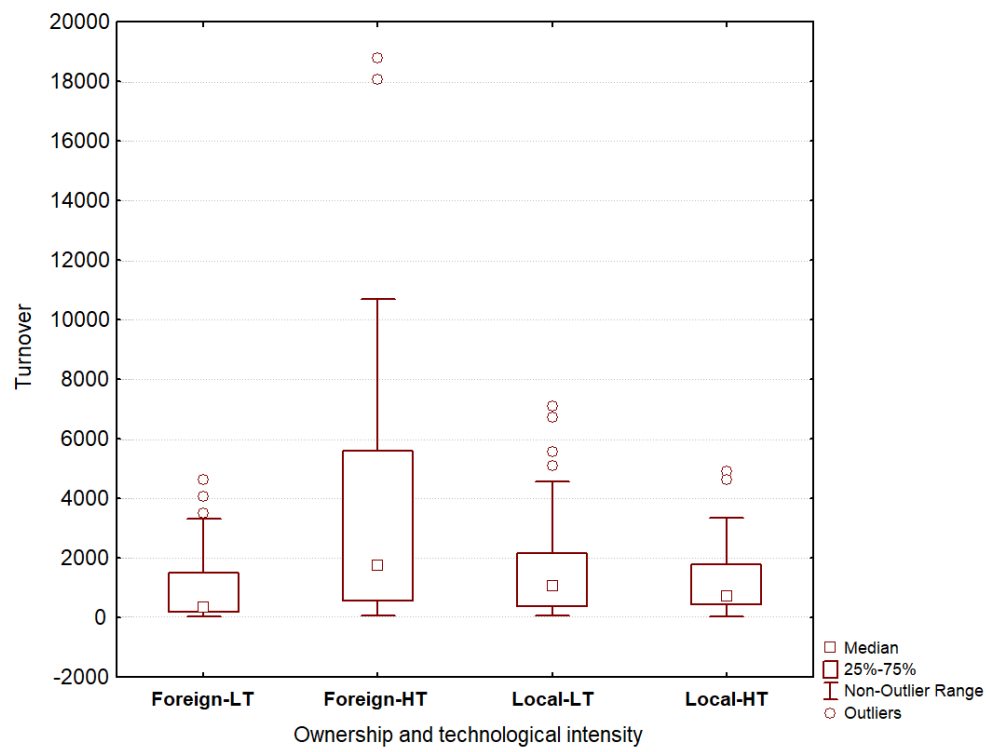

Source: Authors' representation 
In this research, we have applied a statistical analysis based on performing mean difference tests, such as T-tests (Student's T-tests) and ANOVA. Moreover, we used the two-samples Kolmogorov-Smirnoff (KS) test on the equality of continuous one-dimensional probability distributions. A T-test is a statistical test which can be used to compare the means of two groups. Also, it indicates how significant the differences between the independent groups are (Gerald, 2018). Analysis of variance (ANOVA) can be used as an extension of the T-test. ANOVA was used in this paper to check if there were statistically significant differences between the means of the three independent groups - All groups, Above median and Below median - for the considered variables. This test compares the means between these groups, and, at the same time, it determines whether any of those means are statistically significantly different from each other. ANOVA represents the most quoted advanced research method in the economic literature (Ostertagova and Ostertag, 2013). Finally, the Kolmogorov-Smirnoff test represents the best-known test for normality and is a non-parametric test of the equality of continuous onedimensional distributions of probability. We have used the two sample KS test to compare frequency distributions of business units included in the three independent groups - all, big and small business units (Drezner et al., 2010).

Figure 3. Business units' distribution in the EU based on the ownership technological intensity - EU region triad: Western Europe

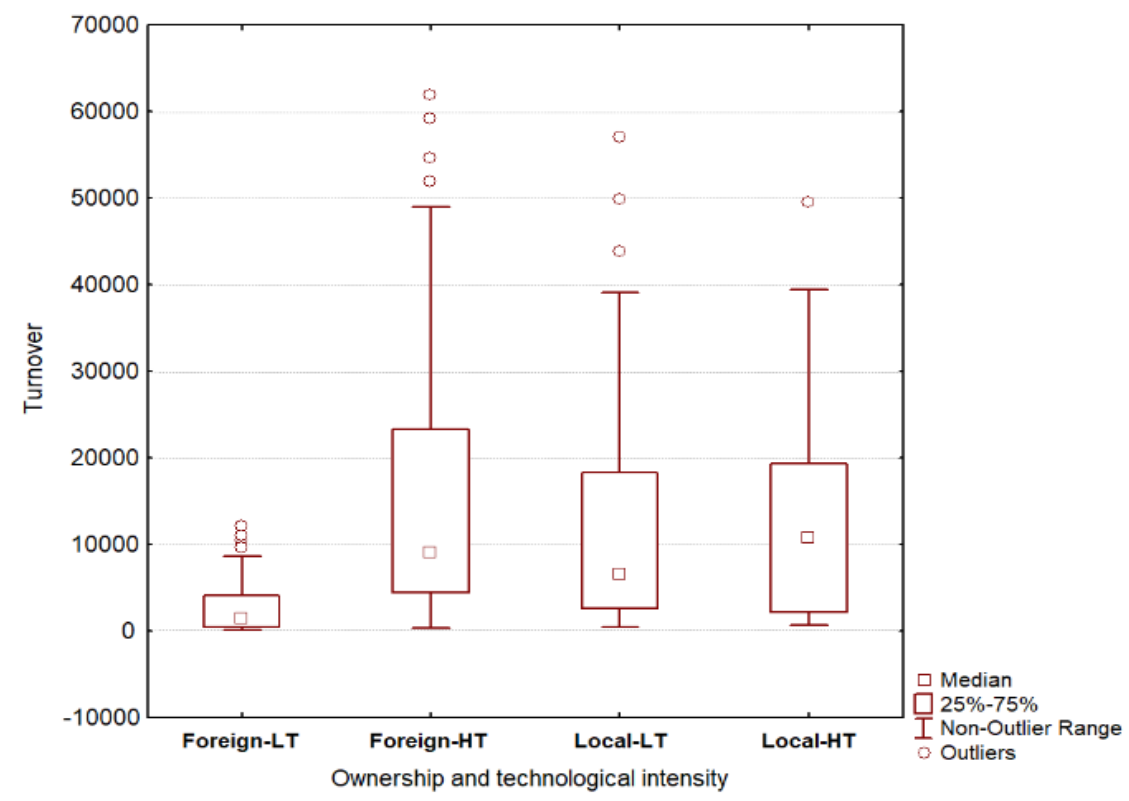

Source: Authors' representation 


\section{Results}

We have calculated the means (simple averages) for each variable and category of business units in the ownership-technological intensity category (see Table 1) and performed t-tests to check whether the mean is statistically different within the four groups of business units: foreign low-tech, foreign high-tech, local low-tech and local high-tech. The findings presented in Table 1 show that, at the overall group level (which does not discriminate in terms of size), foreign high-tech companies had the highest labour productivity in the 2009-2016 period while local low-tech companies have the highest value-added share in turnover but also the highest personnel costs as share in turnover. Also, local low-tech business units seem to perform far worse than the other groups in terms of labour productivity but show the highest investment in turnover. Foreign high-tech business units have the lowest value-added share in turnover but also the lowest personnel costs.

The split in big and small business units demonstrates that foreign high-tech companies enjoy higher labour productivity but the lowest value-added share in turnover and personnel costs in turnover. Foreign low-tech business units are the best in value-added share in turnover, second best in labour productivity but worst in investments as percentage in turnover. Local high-tech have the highest share of personnel costs coupled with the highest investments and gross operating rate - for half of the period (surplus generated by operating activities). Local low-tech seems to be lagging behind in terms of labour productivity and they have low value added or high personnel costs. For smaller sized business units, those included in the foreign high-tech category had the highest labour productivity and second highest gross operating rate, however, the lowest personnel costs and value-added share in turnover. Foreign low-tech is second best in labour productivity and investments, but second worst in personnel costs and value-added. Local high-tech business units are the leaders in gross operating rate, value-added and investments, while local lowtech business units are second best in value added.

Table 1. Means of variables by technological intensity, ownership and size

\begin{tabular}{|c|c|c|c|c|c|c|c|c|c|c|c|c|}
\hline \multirow[t]{2}{*}{ Variable } & \multicolumn{4}{|c|}{ All groups } & \multicolumn{4}{|c|}{ Above median } & \multicolumn{4}{|c|}{ Below median } \\
\hline & $\begin{array}{c}\text { Foreign } \\
\text { HT }\end{array}$ & $\begin{array}{c}\text { Foreign } \\
\text { LT }\end{array}$ & $\begin{array}{c}\text { Local } \\
\text { HT }\end{array}$ & $\begin{array}{l}\text { Local } \\
\text { LT }\end{array}$ & $\begin{array}{c}\text { Foreign } \\
\text { HT }\end{array}$ & $\begin{array}{c}\text { Foreign } \\
\text { LT }\end{array}$ & $\begin{array}{c}\text { Local } \\
\text { HT }\end{array}$ & $\begin{array}{c}\text { Local } \\
\text { LT }\end{array}$ & $\begin{array}{c}\text { Foreign } \\
\text { HT }\end{array}$ & $\begin{array}{c}\text { Foreign } \\
\text { LT }\end{array}$ & $\begin{array}{c}\text { Local } \\
\text { HT }\end{array}$ & $\begin{array}{l}\text { Local } \\
\text { LT }\end{array}$ \\
\hline GOR_09 & 7.90 & 8.06 & 6.67 & 8.78 & 7.51 & 8.80 & 6.57 & 8.95 & 8.29 & 7.31 & 7.22 & 8.76 \\
\hline GOR_10 & 20.80 & 22.18 & 20.43 & 22.49 & 19.23 & 19.10 & 17.82 & 22.49 & 22.38 & 25.25 & 35.22 & 22.49 \\
\hline GOR_11 & 13.75 & 14.36 & 14.41 & 15.26 & 9.41 & 14.47 & 12.18 & 9.51 & 18.10 & 14.25 & 27.08 & 15.90 \\
\hline GOR_12 & 10.14 & 10.07 & 11.34 & 11.00 & 8.37 & 9.08 & 9.77 & 9.24 & 11.92 & 11.06 & 20.23 & 11.20 \\
\hline GOR_13 & 13.59 & 11.64 & 12.44 & 12.97 & 12.63 & 9.16 & 11.30 & 9.20 & 14.54 & 14.11 & 18.89 & 13.39 \\
\hline GOR_14 & 13.68 & 10.26 & 14.32 & 11.43 & 10.76 & 9.53 & 12.14 & 8.54 & 16.61 & 10.99 & 26.62 & 11.75 \\
\hline GOR_15 & 14.65 & 15.55 & 14.53 & 16.10 & 11.84 & 9.85 & 13.87 & 9.16 & 17.47 & 21.25 & 18.29 & 16.87 \\
\hline GOR_16 & 10.05 & 10.54 & 10.90 & 10.68 & 9.66 & 10.40 & 10.90 & 9.53 & 10.44 & 10.68 & 10.90 & 10.80 \\
\hline
\end{tabular}




\begin{tabular}{|c|c|c|c|c|c|c|c|c|c|c|c|c|}
\hline 09 & 2 & 7.99 & 139.03 & 7.15 & 165.06 & 159.68 & 139.39 & 154.65 & 161.18 & 156.29 & 137.02 & 46. \\
\hline SWALP_10 & 93.07 & 173.77 & 164.78 & 156.48 & 198.71 & 168.97 & 164.99 & 160.81 & 187.42 & 178.57 & 163.59 & 156.00 \\
\hline NALP_11 & 93.56 & 173.77 & 164.39 & 157.22 & 194.80 & 169.67 & 165.32 & 162.15 & 192.33 & 177.88 & 159.09 & 156.67 \\
\hline WALP_12 & 177.19 & 168.60 & 156.26 & 155.80 & 174.62 & 164.21 & 154.32 & 160.87 & 179.76 & 172.99 & 167.21 & 155.23 \\
\hline WALP_13 & 177.03 & 172.61 & 155.20 & 154.74 & 173.13 & 166.38 & 154.40 & 162.57 & 180.93 & 178.85 & 159.69 & 153.87 \\
\hline NALP_14 & 182.29 & 175.54 & 159.22 & 157.78 & 182.34 & 168.70 & 160.52 & 156.65 & 182.24 & 182.37 & 151.85 & 157.90 \\
\hline NALP 15 & 191.87 & 174.90 & 168.95 & 156.25 & 191.81 & 170.57 & 171.61 & 159.75 & 191.93 & 179.23 & 153.88 & 155.87 \\
\hline WALP_16 & 186.36 & 175.94 & 169.27 & 159.09 & 193.08 & 170.40 & 172.51 & 160.41 & 179.65 & 181.48 & 150.92 & 158.94 \\
\hline VATurn 09 & 0.23 & 0.26 & 0.26 & 0.30 & 0.22 & 0.26 & 0.25 & 0.27 & 0.25 & 0.25 & 0.30 & 0.30 \\
\hline VATurn 10 & 0.25 & 0.26 & 0.28 & 0.29 & 0.23 & 0.27 & 0.27 & 0.27 & 0.27 & 0.26 & 0.32 & 0.30 \\
\hline VATurn_11 & 0.24 & 0.26 & 0.27 & 0.29 & 0.22 & 0.26 & 0.26 & 0.25 & 0.26 & 0.26 & 0.31 & 0.29 \\
\hline VATurn_12 & 0.23 & 0.25 & 0.26 & 0.29 & 0.21 & 0.26 & 0.25 & 0.25 & 0.24 & 0.25 & 0.31 & 0.29 \\
\hline VATurn_13 & 0.23 & 0.26 & 0.26 & 0.29 & 0.21 & 0.26 & 0.26 & 0.25 & 0.25 & 0.25 & 0.30 & 0.29 \\
\hline VATurn_14 & 0.23 & 0.26 & 0.27 & 0.29 & 0.21 & 0.27 & 0.27 & 0.25 & 0.25 & 0.26 & 0.31 & 0.30 \\
\hline VATurn_15 & 0.24 & 0.27 & 0.27 & 0.29 & 0.22 & 0.27 & 0.27 & 0.26 & 0.26 & 0.26 & 0.31 & 0.30 \\
\hline VATurn_16 & 0.24 & 0.28 & 0.29 & 0.30 & 0.23 & 0.28 & 0.28 & 0.26 & 0.26 & 0.28 & 0.33 & 0.30 \\
\hline GITurn_09 & 0.05 & 0.05 & 0.05 & 0.05 & 0.03 & 0.03 & 0.05 & 0.04 & 0.06 & 0.06 & 0.08 & 0.05 \\
\hline ITurn_10 & 0.04 & 0.04 & 0.05 & 0.05 & 0.03 & 0.03 & 0.04 & 0.04 & 0.05 & 0.05 & 0.07 & 0.05 \\
\hline GITurn_11 & 0.04 & 0.04 & 0.04 & 0.05 & 0.04 & 0.03 & 0.04 & 0.04 & 0.05 & 0.05 & 0.06 & 0.05 \\
\hline GITurn_12 & 0.05 & 0.04 & 0.04 & 0.05 & 0.04 & 0.03 & 0.04 & 0.04 & 0.06 & 0.05 & 0.04 & 0.05 \\
\hline GITurn_13 & 0.04 & 0.04 & 0.05 & 0.04 & 0.04 & 0.03 & 0.04 & 0.04 & 0.05 & 0.06 & 0.07 & 0.04 \\
\hline GITurn_14 & 0.04 & 0.04 & 0.04 & 0.05 & 0.04 & 0.04 & 0.04 & 0.04 & 0.05 & 0.05 & 0.06 & 0.05 \\
\hline ITurn_15 & 0.04 & 0.04 & 0.05 & 0.05 & 0.04 & 0.04 & 0.04 & 0.04 & 0.05 & 0.05 & 0.06 & 0.05 \\
\hline GITurn_16 & 0.04 & 0.33 & 0.05 & 0.05 & 0.04 & 0.04 & 0.04 & 0.04 & 0.05 & 0.63 & 0.06 & 0.05 \\
\hline PcostTurn_09 & 0.16 & 0.18 & 0.19 & 0.21 & 0.14 & 0.17 & 0.19 & 0.18 & 0.17 & 0.18 & 0.22 & 0.21 \\
\hline PcostTurn_10 & 0.14 & 0.17 & 0.18 & 0.19 & 0.13 & 0.17 & 0.17 & 0.17 & 0.15 & 0.17 & 0.19 & 0.20 \\
\hline PcostTurn_11 & 0.13 & 0.16 & 0.17 & 0.19 & 0.12 & 0.16 & 0.16 & 0.16 & 0.15 & 0.17 & 0.18 & 0.19 \\
\hline PcostTurn_12 & 0.14 & 0.17 & 0.17 & 0.19 & 0.13 & 0.16 & 0.17 & 0.16 & 0.14 & 0.17 & 0.18 & 0.19 \\
\hline PcostTurn_13 & 0.14 & 0.17 & 0.17 & 0.19 & 0.13 & 0.17 & 0.17 & 0.16 & 0.15 & 0.16 & 0.18 & 0.19 \\
\hline PcostTurn_14 & 0.14 & 0.17 & 0.17 & 0.19 & 0.13 & 0.17 & 0.17 & 0.16 & 0.15 & 0.16 & 0.19 & 0.19 \\
\hline PcostTurn_15 & 0.14 & 0.17 & 0.17 & 0.19 & 0.13 & 0.17 & 0.17 & 0.17 & 0.15 & 0.17 & 0.21 & 0.20 \\
\hline PcostTurn_16 & 0.14 & 0.17 & 0.18 & 0.19 & 0.13 & 0.18 & 0.17 & 0.17 & 0.16 & 0.17 & 0.22 & 0.20 \\
\hline
\end{tabular}

Source: Author's calculations

Moving forward into our analysis, t-tests (see Table 2) show differences between groups that are statistically significant in the majority of years between foreign high-tech and foreign low-tech for labour productivity, value-added share in turnover and personnel costs share in turnover; foreign high-tech and local high-tech for labour productivity, value-added share in turnover and personnel costs share in turnover; foreign high-tech and local low-tech for labour productivity, value-added share in turnover, personnel costs share in turnover and gross investments share in turnover; foreign low-tech and local low-tech for labour productivity, value-added share in turnover, personnel costs share in turnover and gross investments share in turnover; foreign low-tech and local high-tech for gross operating rate, labour 
productivity and personnel costs share in turnover; local high-tech and local lowtech for all the variables employed.

Table 2. T-tests results

\begin{tabular}{|c|c|c|c|c|c|}
\hline \multirow[t]{2}{*}{ Groups } & GOR & SWALP & VATurn & GITurn & PcostTurn \\
\hline & \multicolumn{5}{|c|}{ All groups } \\
\hline $\begin{array}{l}\text { Foreign HT - Foreign } \\
\text { LT }\end{array}$ & - & $\begin{array}{l}2010-2011, \\
2015\end{array}$ & $\begin{array}{l}2009,2011- \\
2016\end{array}$ & - & $2009-2016$ \\
\hline Foreign HT - Local HT & - & $2009-2015$ & $2009-2016$ & - & $2009-2016$ \\
\hline Foreign HT - Local LT & - & $2009-2016$ & $\begin{array}{l}2009,2011- \\
2015\end{array}$ & $\begin{array}{l}2010,2015- \\
2016\end{array}$ & $2009-2016$ \\
\hline Foreign LT - Local LT & - & $2009-2016$ & 2009-2016 & $\begin{array}{l}2010,2014- \\
2015\end{array}$ & $2009-2016$ \\
\hline Foreign LT - Local HT & 2014 & $\begin{array}{l}2009,2012- \\
2014\end{array}$ & - & - & 2009 \\
\hline \multirow[t]{2}{*}{ Local HT - Local LT } & 2009 & 2015 & $2009-2016$ & $\begin{array}{l}\text { 2011-2012, } \\
2015\end{array}$ & $2010-2015$ \\
\hline & \multicolumn{5}{|c|}{ Above median } \\
\hline $\begin{array}{l}\text { Foreign HT - Foreign } \\
\text { LT }\end{array}$ & - & $\begin{array}{l}\text { 2010-2011, } \\
2015-2016\end{array}$ & $2009-2016$ & - & $2009-2016$ \\
\hline Foreign HT - Local HT & - & $2009-2014$ & 2009-2016 & 2009 & $2009-2016$ \\
\hline Foreign HT - Local LT & - & 2010 & - & - & $\begin{array}{l}\text { 2009-2012, } \\
2014-2016\end{array}$ \\
\hline Foreign LT - Local LT & - & - & - & - & - \\
\hline Foreign LT - Local HT & - & 2009 & - & 2009,2013 & - \\
\hline \multirow[t]{2}{*}{ Local HT - Local LT } & - & - & 2009 & - & - \\
\hline & \multicolumn{5}{|c|}{ Below median } \\
\hline $\begin{array}{l}\text { Foreign HT - Foreign } \\
\text { LT }\end{array}$ & - & - & - & - & - \\
\hline Foreign HT - Local HT & - & - & $2010-2016$ & - & $\begin{array}{l}\text { 2009-2012, } \\
2014-2016\end{array}$ \\
\hline Foreign HT - Local LT & - & - & 2009-2016 & - & $2009-2016$ \\
\hline Foreign LT - Local LT & 2009 & $2010-2016$ & $2009-2016$ & 2016 & $2009-2016$ \\
\hline Foreign LT - Local HT & - & 2014,2016 & $\begin{array}{l}\text { 2010-2014, } \\
2016\end{array}$ & - & $\begin{array}{l}2009,2015- \\
2016\end{array}$ \\
\hline Local HT - Local LT & $\begin{array}{l}2012 \\
2014\end{array}$ & - & - & 2009,2013 & - \\
\hline
\end{tabular}

Source: Author's calculations

To test whether there are significant statistical differences between the four categories of business units, ANOVA tests were performed (see Table 3). According to our findings, the differences between the groups are statistically significant at all levels (above median, below median and all groups) for value-added share in turnover, personnel costs share in turnover and wage-adjusted labour productivity, as shown by p-value lower than $5 \%$. 
Table 3. Analysis of variance (ANOVA) for all groups - all variables

\begin{tabular}{|c|c|c|c|c|c|c|c|c|}
\hline & GOR & GOR & GOR & GOR & GOR & GOR & GOR & GOR \\
\hline & 2009 & 2010 & 2011 & 2012 & 2013 & 2014 & 2015 & 2016 \\
\hline $\begin{array}{c}\text { All } \\
\text { groups }\end{array}$ & $\begin{array}{c}2.915 \\
(0.034)\end{array}$ & $\begin{array}{c}0.111 \\
(0.954)\end{array}$ & $\begin{array}{c}0.099 \\
(0.961)\end{array}$ & $\begin{array}{c}0.270 \\
(0.847)\end{array}$ & $\begin{array}{c}0.240 \\
(0.868)\end{array}$ & $\begin{array}{c}1.699 \\
(0.166)\end{array}$ & $\begin{array}{c}0.122 \\
(0.947)\end{array}$ & $\begin{array}{c}0.563 \\
(0.640)\end{array}$ \\
\hline $\begin{array}{l}\text { Above } \\
\text { median }\end{array}$ & $\begin{array}{c}2.457 \\
(0.064)\end{array}$ & $\begin{array}{c}0.115 \\
(0.951)\end{array}$ & $\begin{array}{c}0.951 \\
(0.417)\end{array}$ & $\begin{array}{c}0.266 \\
(0.850)\end{array}$ & $\begin{array}{c}0.636 \\
(0.593)\end{array}$ & $\begin{array}{c}0.674 \\
(0.569)\end{array}$ & $\begin{array}{c}1.155 \\
(0.328)\end{array}$ & $\begin{array}{c}0.770 \\
(0.512)\end{array}$ \\
\hline $\begin{array}{l}\text { Below } \\
\text { median }\end{array}$ & $\begin{array}{c}1.363 \\
(0.255)\end{array}$ & $\begin{array}{c}0.627 \\
(0.598)\end{array}$ & $\begin{array}{c}1.115 \\
(0.343)\end{array}$ & $\begin{array}{c}1.450 \\
(0.229)\end{array}$ & $\begin{array}{c}0.282 \\
(0.839)\end{array}$ & $\begin{array}{c}4.036 \\
(0.008)\end{array}$ & $\begin{array}{c}0.433 \\
(0.730)\end{array}$ & $\begin{array}{c}0.086 \\
(0.967)\end{array}$ \\
\hline & $\begin{array}{c}\text { SWALP } \\
2009\end{array}$ & $\begin{array}{c}\text { SWALP } \\
2010\end{array}$ & $\begin{array}{c}\text { SWALP } \\
2011\end{array}$ & $\begin{array}{c}\text { SWALP } \\
2012\end{array}$ & $\begin{array}{c}\text { SWALP } \\
2013\end{array}$ & $\begin{array}{c}\text { SWALP } \\
2014\end{array}$ & $\begin{array}{c}\text { SWALP } \\
2015\end{array}$ & $\begin{array}{c}\text { SWALP } \\
2016\end{array}$ \\
\hline $\begin{array}{c}\text { All } \\
\text { groups }\end{array}$ & $\begin{array}{c}6.103 \\
(0.000)\end{array}$ & $\begin{array}{l}11.436 \\
(0.000)\end{array}$ & $\begin{array}{l}10.220 \\
(0.000)\end{array}$ & $\begin{array}{c}6.136 \\
(0.000) \\
\end{array}$ & $\begin{array}{c}7.941 \\
(0.000)\end{array}$ & $\begin{array}{c}7.411 \\
(0.000)\end{array}$ & $\begin{array}{c}8.820 \\
(0.000)\end{array}$ & $\begin{array}{c}6.732 \\
(0.000) \\
\end{array}$ \\
\hline $\begin{array}{l}\text { Above } \\
\text { median }\end{array}$ & $\begin{array}{c}3.716 \\
(0.013)\end{array}$ & $\begin{array}{c}5.179 \\
(0.002)\end{array}$ & $\begin{array}{c}3.133 \\
(0.027)\end{array}$ & $\begin{array}{c}2.366 \\
(0.072)\end{array}$ & $\begin{array}{c}1.928 \\
(0.126)\end{array}$ & $\begin{array}{c}2.098 \\
(0.102)\end{array}$ & $\begin{array}{c}1.664 \\
(0.176)\end{array}$ & $\begin{array}{c}2.156 \\
(0.095)\end{array}$ \\
\hline $\begin{array}{l}\text { Below } \\
\text { median }\end{array}$ & $\begin{array}{c}2.348 \\
(0.073)\end{array}$ & $\begin{array}{c}6.696 \\
(0.000)\end{array}$ & $\begin{array}{c}7.614 \\
(0.000)\end{array}$ & $\begin{array}{c}4.576 \\
(0.004)\end{array}$ & $\begin{array}{c}7.305 \\
(0.000)\end{array}$ & $\begin{array}{c}6.768 \\
(0.000)\end{array}$ & $\begin{array}{c}8.886 \\
(0.000)\end{array}$ & $\begin{array}{c}6.837 \\
(0.000)\end{array}$ \\
\hline & $\begin{array}{l}\text { VATurn } \\
2009\end{array}$ & $\begin{array}{l}\text { VATurn } \\
2010\end{array}$ & $\begin{array}{l}\text { VATurn } \\
2011\end{array}$ & $\begin{array}{l}\text { VATurn } \\
2012\end{array}$ & $\begin{array}{l}\text { VATurn } \\
2013\end{array}$ & $\begin{array}{c}\text { VATurn } \\
2014\end{array}$ & $\begin{array}{l}\text { VATurn } \\
2015\end{array}$ & $\begin{array}{l}\text { VATurn } \\
2016\end{array}$ \\
\hline $\begin{array}{c}\text { All } \\
\text { groups }\end{array}$ & $\begin{array}{l}15.741 \\
(0.000)\end{array}$ & $\begin{array}{c}8.785 \\
(0.000)\end{array}$ & $\begin{array}{c}9.753 \\
(0.000)\end{array}$ & $\begin{array}{l}13.358 \\
(0.000)\end{array}$ & $\begin{array}{l}12.397 \\
(0.000)\end{array}$ & $\begin{array}{l}13.172 \\
(0.000)\end{array}$ & $\begin{array}{l}11.112 \\
(0.000)\end{array}$ & $\begin{array}{l}11.054 \\
(0.000)\end{array}$ \\
\hline $\begin{array}{l}\text { Above } \\
\text { median }\end{array}$ & $\begin{array}{c}3.996 \\
(0.009)\end{array}$ & $\begin{array}{c}2.796 \\
(0.042)\end{array}$ & $\begin{array}{c}3.927 \\
(0.010)\end{array}$ & $\begin{array}{c}3.677 \\
(0.013)\end{array}$ & $\begin{array}{c}4.758 \\
(0.003)\end{array}$ & $\begin{array}{c}5.266 \\
(0.002)\end{array}$ & $\begin{array}{c}4.421 \\
(0.005)\end{array}$ & $\begin{array}{c}5.057 \\
(0.002)\end{array}$ \\
\hline $\begin{array}{l}\text { Below } \\
\text { median }\end{array}$ & $\begin{array}{l}10.132 \\
(0.000)\end{array}$ & $\begin{array}{c}7.642 \\
(0.000)\end{array}$ & $\begin{array}{c}5.860 \\
(0.001)\end{array}$ & $\begin{array}{c}9.614 \\
(0.000)\end{array}$ & $\begin{array}{c}7.555 \\
(0.000)\end{array}$ & $\begin{array}{c}8.675 \\
(0.000)\end{array}$ & $\begin{array}{c}6.486 \\
(0.000)\end{array}$ & $\begin{array}{c}7.181 \\
(0.000)\end{array}$ \\
\hline & $\begin{array}{c}\text { GITurn } \\
2009\end{array}$ & $\begin{array}{c}\text { GITurn } \\
2010\end{array}$ & $\begin{array}{c}\text { GITurn } \\
2011\end{array}$ & $\begin{array}{c}\text { GITurn } \\
2012 \\
\end{array}$ & $\begin{array}{c}\text { GITurn } \\
2013\end{array}$ & $\begin{array}{c}\text { GITurn } \\
2014\end{array}$ & $\begin{array}{c}\text { GITurn } \\
2015\end{array}$ & $\begin{array}{c}\text { GITurn } \\
2016\end{array}$ \\
\hline $\begin{array}{c}\text { All } \\
\text { groups }\end{array}$ & $\begin{array}{c}0.413 \\
(0.744)\end{array}$ & $\begin{array}{c}2.191 \\
(0.088)\end{array}$ & $\begin{array}{c}0.946 \\
(0.418)\end{array}$ & $\begin{array}{c}1.803 \\
(0.146) \\
\end{array}$ & $\begin{array}{c}0.145 \\
(0.933)\end{array}$ & $\begin{array}{c}2.559 \\
(0.055)\end{array}$ & $\begin{array}{c}2.998 \\
(0.031)\end{array}$ & $\begin{array}{c}1.892 \\
(0.130)\end{array}$ \\
\hline $\begin{array}{l}\text { Above } \\
\text { median }\end{array}$ & $\begin{array}{c}3.854 \\
(0.010)\end{array}$ & $\begin{array}{c}2.076 \\
(0.105)\end{array}$ & $\begin{array}{c}0.752 \\
(0.522)\end{array}$ & $\begin{array}{c}1.002 \\
(0.393)\end{array}$ & $\begin{array}{c}2.095 \\
(0.102)\end{array}$ & $\begin{array}{c}1.376 \\
(0.251)\end{array}$ & $\begin{array}{c}1.741 \\
(0.160)\end{array}$ & $\begin{array}{c}0.396 \\
(0.756)\end{array}$ \\
\hline $\begin{array}{l}\text { Below } \\
\text { median }\end{array}$ & $\begin{array}{c}1.462 \\
(0.226)\end{array}$ & $\begin{array}{c}1.151 \\
(0.329)\end{array}$ & $\begin{array}{c}0.670 \\
(0.571)\end{array}$ & $\begin{array}{c}1.207 \\
(0.308)\end{array}$ & $\begin{array}{c}1.459 \\
(0.227)\end{array}$ & $\begin{array}{c}0.665 \\
(0.575)\end{array}$ & $\begin{array}{c}0.668 \\
(0.573)\end{array}$ & $\begin{array}{c}2.310 \\
(0.077)\end{array}$ \\
\hline & $\begin{array}{l}\text { PcostTurn } \\
2009\end{array}$ & $\begin{array}{l}\text { PcostTurn } \\
2010\end{array}$ & $\begin{array}{l}\text { PcostTurn } \\
2011\end{array}$ & $\begin{array}{l}\text { PcostTurn } \\
2012\end{array}$ & $\begin{array}{l}\text { PcostTurn } \\
2013\end{array}$ & $\begin{array}{l}\text { PcostTurn } \\
2014\end{array}$ & $\begin{array}{l}\text { PcostTurn } \\
2015\end{array}$ & $\begin{array}{l}\text { PcostTurn } \\
2016\end{array}$ \\
\hline $\begin{array}{c}\text { All } \\
\text { groups }\end{array}$ & $\begin{array}{l}16.071 \\
(0.000)\end{array}$ & $\begin{array}{l}15.177 \\
(0.000)\end{array}$ & $\begin{array}{l}14.503 \\
(0.000)\end{array}$ & $\begin{array}{l}15.251 \\
(0.000)\end{array}$ & $\begin{array}{l}12.610 \\
(0.000)\end{array}$ & $\begin{array}{l}12.971 \\
(0.000)\end{array}$ & $\begin{array}{l}15.460 \\
(0.000)\end{array}$ & $\begin{array}{c}9.953 \\
(0.000)\end{array}$ \\
\hline $\begin{array}{l}\text { Above } \\
\text { median }\end{array}$ & $\begin{array}{c}6.161 \\
(0.001)\end{array}$ & $\begin{array}{c}6.317 \\
(0.000)\end{array}$ & $\begin{array}{c}6.030 \\
(0.001)\end{array}$ & $\begin{array}{c}5.486 \\
(0.001)\end{array}$ & $\begin{array}{c}4.909 \\
(0.003)\end{array}$ & $\begin{array}{c}5.353 \\
(0.001)\end{array}$ & $\begin{array}{c}5.118 \\
(0.002)\end{array}$ & $\begin{array}{c}4.047 \\
(0.008)\end{array}$ \\
\hline $\begin{array}{l}\text { Below } \\
\text { median }\end{array}$ & $\begin{array}{c}8.263 \\
(0.000)\end{array}$ & $\begin{array}{c}7.646 \\
(0.000)\end{array}$ & $\begin{array}{c}6.567 \\
(0.000)\end{array}$ & $\begin{array}{c}7.914 \\
(0.000)\end{array}$ & $\begin{array}{c}6.993 \\
(0.000)\end{array}$ & $\begin{array}{c}7.490 \\
(0.000)\end{array}$ & $\begin{array}{c}9.778 \\
(0.000)\end{array}$ & $\begin{array}{c}9.322 \\
(0.000)\end{array}$ \\
\hline
\end{tabular}

Note: The table reports F-test values and p-values in parentheses. Values in italic indicate statistically significant differences between categories of business units.

Source: Author's calculations

Next, the dynamics of considered variables between 2009 and 2016 demonstrates that local high-tech business units had the highest growth for GOR, SWALP and VATurn, while foreign low-tech business units had the highest growth in GITurn and PcostTurn (Table 4). This indicates that local companies operating in high-tech industries had higher productivity and profitability, but also created more 
value, while investments and personnel costs were higher in foreign-owned business units operating in the low-tech sector. Continuing with variables' dynamics but, this time, as shown by ANOVA (see Table 5), we observe that it is the variable in whose case differences are statistically significant among all categories of businesses, regardless of their size, while business units have statistically significant means for the considered categories in terms of VATurn at all groups and below median (small size business units). PcostTurn shows statistically significant mean growth rates only at all groups level.

Table 4. Growth of variables between 2009 and 2016 by technological intensity, ownership and size (means of groups)

\begin{tabular}{|c|c|c|c|c|c|c|c|c|c|c|c|c|}
\hline & \multicolumn{4}{|c|}{ All groups } & \multicolumn{4}{|c|}{ Above median } & \multicolumn{4}{|c|}{ Below median } \\
\hline & $\begin{array}{c}\text { Foreign } \\
\text { HT }\end{array}$ & $\begin{array}{c}\text { Foreign } \\
\text { LT }\end{array}$ & $\begin{array}{c}\text { Local } \\
\text { HT }\end{array}$ & $\begin{array}{c}\text { Local } \\
\text { LT }\end{array}$ & $\begin{array}{c}\text { Foreign } \\
\text { HT }\end{array}$ & $\begin{array}{c}\text { Foreign } \\
\text { LT }\end{array}$ & $\begin{array}{l}\text { Local } \\
\text { HT }\end{array}$ & $\begin{array}{c}\text { Local } \\
\text { LT }\end{array}$ & $\begin{array}{c}\text { Foreign } \\
\text { HT }\end{array}$ & $\begin{array}{c}\text { Foreign } \\
\text { LT }\end{array}$ & $\begin{array}{c}\text { Local } \\
\text { HT }\end{array}$ & $\begin{array}{c}\text { Local } \\
\text { LT }\end{array}$ \\
\hline GOR_16/09 & 1.58 & 1.57 & 1.76 & 1.32 & 1.77 & 1.56 & 1.85 & 1.20 & 1.38 & 1.59 & 1.24 & 1.33 \\
\hline SWALP_16/09 & 1.18 & 1.15 & 1.39 & 1.09 & 1.19 & 1.10 & 1.32 & 1.04 & 1.17 & 1.21 & 1.79 & 1.10 \\
\hline VATurn_16/09 & 1.08 & 1.13 & 1.25 & 1.01 & 1.07 & 1.09 & 1.19 & 0.98 & 1.08 & 1.17 & 1.56 & 1.01 \\
\hline GITurn_16/09 & 0.74 & 16.12 & 2.61 & 1.48 & 1.19 & -0.00 & 2.93 & 0.47 & 1.48 & 31.05 & 0.85 & 1.59 \\
\hline PcostTurn_16/09 & 0.93 & 1.01 & 0.95 & 0.93 & 0.91 & 1.05 & 0.94 & 0.94 & 0.95 & 0.97 & 0.99 & 0.93 \\
\hline
\end{tabular}

Note: Values in this table indicate the ratio of variables in 2016 versus 2009.

Source: Author's calculations

Table 5. Analysis of variance (ANOVA) for all groups - variables' change 2009 to 2016

\begin{tabular}{lccc}
\hline & \multicolumn{3}{c}{ F-test and p-values (in parantheses) } \\
\hline GOR_16/09 & All groups & Above median & Below median \\
\hline SWALP_16/09 & $0.477(0.699)$ & $0.190(0.903)$ & $0.254(0.858)$ \\
\hline VATurn_16/09 & $5.474(0.001)$ & $3.796(0.011)$ & $4.953(0.002)$ \\
\hline GITurn_16/09 & $5.326(0.001)$ & $2.151(0.095)$ & $5.321(0.001)$ \\
\hline PcostTurn_16/09 & $1.382(0.248)$ & $1.119(0.343)$ & $1.705(0.167)$ \\
\hline
\end{tabular}

Note: Bolded values indicate statistically significant differences between categories of business units.

Source: Author's calculations

Table 6 presents the results of KS tests. We notice differences between groups that are statistically significant in the majority of years between foreign high-tech and foreign low-tech for value-added share in turnover and personnel costs share in turnover; foreign high-tech and local high-tech for labour productivity, value-added share in turnover and personnel costs share in turnover; foreign high-tech and local low-tech for labour productivity, value-added share in turnover, personnel costs share in turnover and gross investments share in turnover; foreign low-tech and local 
low-tech for labour productivity, value-added share in turnover, personnel costs share in turnover and gross investments share in turnover; foreign low-tech and local high-tech for labour productivity, value-added share in turnover and personnel costs share in turnover; local high-tech and local low-tech for gross investments share in turnover.

Table 6. Results of Kolmogorov-Smirnoff tests

\begin{tabular}{lccccc}
\hline \multirow{1}{*}{ Groups } & GOR & SWALP & VA/TURN & GI/TURN & PCOST/TURN \\
\cline { 2 - 6 } & \multicolumn{5}{c}{ All groups } \\
\hline Foreign HT - Foreign LT & - & 2011 & $2012 ; 2014-$ & $2010-2012 ;$ \\
& & 2016 & $2014-2016$ \\
\hline Foreign HT - Local HT & 2009 & $2009-2011 ;$ & $2009-2016$ & - & $2009-2016$ \\
& & $2013-2015$ & & \\
\hline Foreign HT - Local LT & - & $2009-2016$ & $2009-2016$ & $2009-2011 ;$ & $2009-2016$ \\
& & & & $2013-2016$ & \\
\hline Foreign LT - Local LT & - & $2009-2016$ & $2009-2016$ & $2009-2011 ;$ & $2009-2010 ; 2012-$ \\
\hline Foreign LT - Local HT & - & $2009 ; 2013-$ & 2010 & $2015-2016$ & - \\
\hline Local HT - Local LT & 2009 & - & 2009 & 2016 \\
\end{tabular}

\begin{tabular}{|c|c|c|c|c|c|}
\hline & \multicolumn{5}{|c|}{ Above median } \\
\hline Foreign HT - Foreign LT & - & $2010-2012$ & 2009-2016 & - & $2009-2016$ \\
\hline Foreign HT - Local HT & - & $2009-2016$ & $2009-2016$ & 2009 & $2009-2016$ \\
\hline Foreign HT - Local LT & - & $2010 ; 2014$ & - & 2015 & 2010 \\
\hline Foreign LT - Local LT & - & - & - & $2014-2015$ & - \\
\hline Foreign LT - Local HT & - & 2009 & - & 2009-2010 & - \\
\hline \multirow[t]{2}{*}{ Local HT - Local LT } & - & 2009 & - & - & - \\
\hline & \multicolumn{5}{|c|}{ Below median } \\
\hline Foreign HT - Foreign LT & 2011 & - & - & - & - \\
\hline Foreign HT - Local HT & 2012 & - & $2009-2016$ & $\begin{array}{l}\text { 2009-2011; } \\
\text { 2013-2014 }\end{array}$ & $\begin{array}{c}2009-2010 ; 2014- \\
2016\end{array}$ \\
\hline Foreign HT - Local LT & - & $2010-2011$ & $\begin{array}{l}2009 ; 2011- \\
2016\end{array}$ & $2010 ; 2015$ & $2009-2016$ \\
\hline Foreign LT - Local LT & - & $2010-2016$ & $2009-2016$ & - & $\begin{array}{c}2009-2010 ; 2012- \\
2016\end{array}$ \\
\hline Foreign LT - Local HT & $\begin{array}{l}2011- \\
2012\end{array}$ & - & $2009-2016$ & $2010 ; 2013$ & $\begin{array}{c}2009-2010 ; 2015- \\
2016\end{array}$ \\
\hline Local HT - Local LT & $\begin{array}{l}2011- \\
2012\end{array}$ & - & - & $2010 ; 2013$ & 2016 \\
\hline
\end{tabular}

Source: Author's calculations 


\section{Conclusions}

Our paper undertakes a comparative analysis of the business performance of a set of eleven industries from the manufacturing sector in the European Union with the objective of investigating the industry-specific evolution in the years after the Global financial crisis. The final aim of our endeavour resides in highlighting the lessons to be learned in the period after the crisis generated by the current pandemic.

We discover that the regional location plays a smaller role in discriminating performance between foreign and locally-owned companies and we do not find a clear-cut dominance of foreign-owned companies against their locally-owned peers. Locally-owned companies have an edge against foreign-owned companies for GI share in turnover and VA share in turnover while foreign-owned companies have an advantage over locally-owned companies for personnel cost shares in turnover and labour productivity.

Most local low-tech companies are smaller in size than their local high-tech counterparts, regardless of the East-West axis. When it comes to foreign low-tech, the Eastern Europe companies seem to be smaller with regards to size than their Western counterparts. The same observation applies to foreign high-tech Eastern companies, which are smaller in size than their Western high-tech counterparts. High-tech companies are generally bigger in size than the low-tech companies, as measured by the median. If a closer look is taken at the split between foreign and local, we observe that foreign companies are equally small and big while local companies are mostly smaller in size.

Business recovery after the GFC has taken place at a different pace for these companies, but size, ownership, and level of technological intensity are relevant drivers of the recovery. Larger companies dominated small ones in profitability growth, and this dominance is mostly observable in the high-tech sector. On the other hand, small businesses have seen their productivity increase faster, as well as their value-added share in turnover and gross investment share in turnover (the later except for Local high-tech business units). Interestingly, the share of personnel costs in turnover declined for all categories of business units (except for big foreign-owned units in the low-tech sector). This recovery landscape suggests a higher flexibility of smaller companies, mostly reflected in productivity gains, but also a focus of big businesses on profitability, supported by their size. During the same period, better personnel cost management was implemented by all categories of business units, as reflected by the drop in the importance of personnel costs in turnover.

Because of the crisis, foreign-owned companies should consider a business restructuring, including a reconsideration of "foreignness liability". Also, locallyowned companies will need to consolidate and further develop their businesses once the current crisis is over. Moreover, the government's response to help smaller companies overcome the pandemic crisis by helping them find new markets or 
digitize more rapidly might prove critical. Taking into consideration the current pandemic, building resilience into the organization is more important than ever.

Concerning the research limits, it is important to mention that the regional division considered, although valuable for highlighting business performance differences within the EU, might play a less important role for performance. Also, we know that many EU companies are affiliates of multinational groups with designed and implemented strategies aimed at group performance and not necessarily at unit performance optimisation.

\section{References}

Applegate, L.M., Harreld, B. and Welch, J. (2009), Don't Just Survive--thrive: Leading Innovation in Good Times and Bad, Harvard Business School Working paper, pp. 90127.

Božić, L. and Botrić, V. (2017), Innovation investment decisions: are post (transition) economies different from the rest of the EU?, Eastern Journal of European Studies, 8(2), pp. 25-43.

Cainelli, G., Ganau, R. and Modica, M. (2018), Industrial relatedness and regional resilience in the European Union, Papers in regional science, 98(2), pp. 1-24. https://doi.org/10.1111/pirs.12377

Cowling, M., Liu, W. and Zhang, N. (2018), Did firm age, experience and access to global finance count? SME performance after the global financial crisis, Journal of evolutionary economics, 28(1), pp. 77-100. https://doi.org/10.1007/s00191-017-0502-z

Cucculelli, M. and Bettinelli, C. (2015), Corporate governance in family firms, learning and reaction to recession: evidence from Italy, Futures, 75, pp. 92-103. https://doi.org/10.1016/j.futures.2015.10.011

Cucculelli, M. and Peruzzi, V. (2018), Post-crisis firm survival, business model changes and learning: evidence from the Italian manufacturing industry, Small business economics, 54(2), pp. 459-474. https://doi.org/10.1007/s11187-018-0044-2

Damiani, M. and Uvalic, M. (2014), Industrial development in the EU: lessons for the future member states?, Croatian economic survey, 16(1), pp. 5-48. https://doi.org/10.1007/s11187-018-0044-2

Drezner, Z., Turel, O. and Zerom, D. (2010), A Modified Kolmogorov-Smirnov Test for Normality, Communication in Statistics- Simulation and Computation, 39(4), pp. 693 704. https://doi.org/10.1080/03610911003615816

Gerald, B. (2018), A Brief Review of Independent, Dependent and One Sample t-test, International Journal of Applied Mathematics and Theoretical Physics, 4(2), pp. 50-54. https://doi.org/10.11648/j.ijamtp.20180402.13

Haq, I. (2018), Impact of innovation on economic development: cross-nation comparison of Canada, South Korea and Pakistan, Journal of Economic Info, 5(3), pp. 7-15. https://doi.org/10.31580/jei.v5i3.96 
Haraguchi, N., Cheng, C.F.C. and Smeets, E. (2017), The importance of manufacturing in economic development: has this changed?, World Development, 93, pp. 293-315. https://doi.org/10.1016/j.worlddev.2016.12.013

Hausman, A. and Johnston, W.J. (2014), The role of innovation in driving the economy: Lessons from the global financial crisis, Journal of Business Research, 67(1), pp. 2720-2726. https://doi.org/10.1016/j.jbusres.2013.03.021

Herciu, M. (2015), Challenges for business competitiveness from managerial and knowledge economy perspectives, Studies in Business and Economics, 10(3), pp. 32-40. https://doi.org/10.1515/sbe-2015-0033

Karacay, M. (2017), Slack-performance relationship before, during and after a financial crisis: empirical evidence from European manufacturing firms, Birmingham Business School.

Norris-Dabla, E., Kersting, E. and Verdier. G. (2010), Firm productivity, innovation and financial development, IMF Working Paper Strategy, 10/49, Policy and Review and African development.

Notta, O. and Vlachvei, A. (2014), The impact of financial crisis on firm performance in case of Greek food manufacturing firms, Procedia Economics and Finance, 14, pp. 454460. https://doi.org/10.1016/S2212-5671(14)00734-5

Ostertagova, E. and Ostertag, O. (2013), Methodology and Application of One-way ANOVA, American Journal of Mechanical Engineering, 1(7), pp. 256-261. https://doi.org/10.4028/www.scientific.net/AMM.611.115

Pece, A.M., Oros, O.E. and Salisteanu, F. (2015), Innovation and economic growth: An empirical analysis for CEE countries, Procedia Economics and Finance, 26, pp. 461467. https://doi.org/10.1016/S2212-5671(15)00874-6

Petrariu, I.R., Bumbac, R. and Ciobanu, R. (2013), Innovation: a path to competitiveness and economic growth: The case of CEE countries, Theoretical and Applied Economics, 20(5), pp. 15-26 (retrieved from http://store.ectap.ro/articole/857.pdf).

Popescu, A.I. (2013), Product Innovation Strategies on Emerging Markets: Bringing Theory and Practice Together, European Journal of Interdisciplinary Studies, 5(2), pp. 15-30.

Storrie, D.W. (2019), The future of manufacturing in Europe, Publications Office of the European Union (rerteieved from https://www.eurofound. europa.eu/publications/report/2019/the-future-of-manufacturing-in-europe).

UNFCCC (2015), Paris Agreement, Paris, 2015.

Van Ark, B. and Jager, K. (2017), Recent trends in Europe's output and productivity growth performance at the sector level, 2002-2015, International productivity monitor, 33, pp. 8-23.

Voulgaris, F., Agiomirgianakis, G. and Papadogonas, T. (2015), Job creation and job destruction in economic crisis at firm level: the case of Greek manufacturing sectors, International economics and economic policy, 12, pp. 21-39. https://doi.org/10.1007/s10368-014-0287-6 